\title{
Assessment of reuse, recycle, and recoverable potential of solid waste
}

\author{
Meseret Dawit ${ }^{1,3,4^{*}}$, Habtamu Hailu ${ }^{1}$, and Arbo Feyisa ${ }^{2}$ \\ ${ }^{1}$ Haramaya Institute of Technology, 138 Dire Dawa, Haramaya University, Ethiopia \\ ${ }^{2}$ College of Agriculture and Environmental Science, Haramaya University, Ethiopia \\ ${ }^{3}$ Faculty of Civil Engineering and Geosciences, TU Delft, 2600 GA, Netherlands \\ ${ }^{4}$ IHE-Delft Institute for Water Education, Delft 2601 DA, Netherlands
}

\begin{abstract}
A study was conducted to assess the reuse, recycle, and recoverable potential of Municipal Solid Waste (MSW). Generation rate, waste type, and physicochemical analysis of MSW were evaluated. Results of MSW analysis indicated that the total amount of MSW generation rate per day at Haramaya University (HU) is estimated to be $2608.56 \mathrm{~kg} /$ day. The per capita solid waste generation rate is estimated to be 0.134 $\mathrm{kg} / \mathrm{cap} /$ day. The three waste categories that contributed the greatest proportion of the total sorted waste at all sources are compostable organic matter $(57.31 \%)$, papers $(16.26 \%)$, and fines $(10.98 \%)$ respectively. These three waste categories accounted for approximately $84.55 \%$ of the total waste sorted. The remaining $15.45 \%$ of the sorted waste were plastic material $(5.82 \%)$, miscellaneous $(4.45 \%)$, cardboards $(2.37 \%)$, metals $(1.30 \%)$, glass $(0.87 \%)$, and textiles $(0.63 \%)$. The particle size distribution of compostable organic matter is $42.76 \%$ (greater than $50 \mathrm{~mm}$ ), $53.2 \%$ (between $10-50 \mathrm{~mm}$ ), and $4.04 \%$ (less than $10 \mathrm{~mm}$ ). The result shows that a large proportion of compostable organic waste is found in the particle size range of $10-50 \mathrm{~mm}$. The physicochemical composition of selected compostable organic waste was compared with standard values suitable for the composting process. The study further revealed that there has been a generation rate of potentially recyclable were 169.45 tonnes/year papers and carton, 59.49 tonnes/year plastic material, and 11.82 tonnes/year metals (can). These materials should be collected separately (source separation) and can also be a means of income generation to the institute.
\end{abstract}

\section{Introduction}

Human activities generate waste materials that are often discarded because they are considered useless. These wastes usually are solid and the word waste suggests that the material is useless and unwanted [1]. The estimated quantity of Municipal Solid Waste generated worldwide is 1.7-1.9 billion metric tons [2]. The quantity of solid waste generated has increased significantly and its characteristics have changed as a result of

\footnotetext{
* Corresponding author: mesedawit@gmail.com or m.dawit-teweldebrihan@un-ihe.org
} 
changes in people's lifestyles due to rapid industrialization and urbanization. Rapid population growth and an increase in economic activities combined with a lack of training in modern solid waste management practices complicate the efforts to improve the solid waste service [3].

Reducing the number of wastes that have to be handled, transported and disposed of in a landfill could lead to two main results in a reduction of the institutional expenditure dedicated to waste management and an increase of the useful life of the sanitary landfill. Besides these benefits, a reduction in the amount of waste produced by institutions would also have environmental and social benefits [4]. Institutions can easily fashion out their mini-solid waste management systems within the comprehensive MSW management system framework. With such systems in place in institutions, resource recovery and waste recycling can more easily and effectively be incorporated, reducing the pressure on solid waste disposal sites. Also, colleges and universities have the moral and ethical obligation to act responsibly towards the environment; they would be expected to be leaders in the movement for environmental protection [5-7]. Specifically, it would be expected that universities would drive the efforts towards responsible waste management. It would set an example for the students and the community besides cost reduction for waste management.

Waste management programs in higher education institutions in industrialized countries began more than 20 years ago and varied from voluntary and local efforts to institutionalized programs [8]. Some of the higher education initiatives focused on recycling and waste reduction have been very successful. Recycling programs are one of the most popular environmental initiatives; in the USA, $80 \%$ of the colleges and universities have institutionalized waste programs [9].

The type of decision making that leads to adequate solid waste management requires a sound understanding of the composition and the processes that determine the generation of waste. Particular attention should be paid to the waste generation sources since the characteristics and composition of the waste differ according to their origin [10]. Waste management programs based on the knowledge of the waste composition would be more successful than the ambitious programs copied from somewhere else [11]. For this reason, when proposing waste management strategies, these must be based on the reality of the generating source. Thus, it is important to know the characteristics of the waste. However, In Ethiopian Universities, there is little, or no study has been done regarding waste characterization and quantification for further analysis of recyclable and recoverable potential of wastes. No reliable data were recorded on solid waste characteristics and generation rate within the campuses of Haramaya University. Hence, the study is fundamental and unique in addressing the important and long-term potential of the solid waste generation. Therefore, the primary aim of this paper is to reduce the gap between the need for this type of study and to explore the reuse, recycle, and recovery potential of solid waste as a means of reducing HU MSW volume with a relative look at the utilization of resources.

\section{Materials and methods}

Waste measurements were carried out at student's halls of residence, offices, library, student cafeteria, student lounges, staff lounges, staff residence, laboratories, and classrooms. The selected measurement places were the ones that were believed to represent primary and typical sources of waste. This was in line with the need to get a representative spectrum of sources and types of MSW from the institution. The conceptual layout of this study is shown in Fig. 1. 


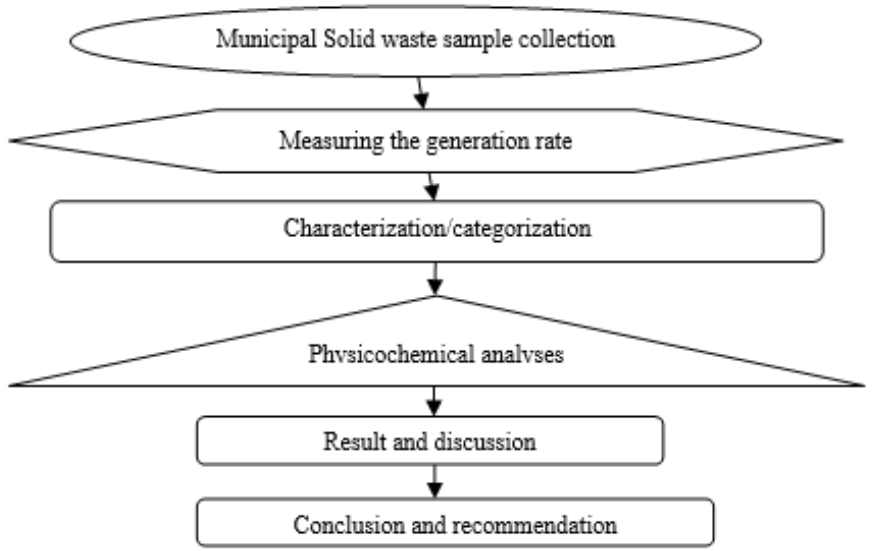

Fig. 1. Overview of the general methodology.

\subsection{Sample size determination}

The mathematical formula developed by Cochran was used to determine sample size (n) with the desired degree of precision for the general population [12]. In this case, population variable $(\mathrm{P})$ is house unit variable, and is given as (Eq. 1):

$$
n=\frac{N Z^{2} P Q}{d^{2}(N-1)+Z^{2} P Q}
$$

where $\mathrm{n}$ denotes sample size of housing units, $\mathrm{P}$ represents the residential houses, $\mathrm{Q}$ represents the non-residential houses (offices, classrooms, etc.) $=1-\mathrm{P}, \mathrm{N}$ denotes the total number of housing units, $\mathrm{Z}$ denotes the standardized normal variable and its value that corresponds to $95 \%$ confidence interval equals 1.96 and d shows the allowable error $(0.05)$

$$
n=\frac{4762 \times(1.96)^{2} \times 0.72 \times 0.28}{0.05^{2} \times(4762-1)+1.96^{2} \times 0.72 \times 0.28}=297
$$

According to data obtained from Haramaya University, there are about 2500 housing units $(\mathrm{N})$ : out of these around $80 \%(\mathrm{P})$ are of residential (staff residence and student dormitories) and the rest $20 \%(\mathrm{Q})$ is for non-residential (classrooms, offices, laboratories, library, shop, student lounge, cafes, and stuff lunge). Therefore, the minimum sample size calculated was found to be 297 .

\subsection{Sampling techniques}

Stratified and random sampling techniques were employed to select the houses for the study. Before sample collection for the analysis, preliminary site visits were made to assess the esthetic quality of the study area, to establish a basis for evaluating how study facts and figures correlate with visual evidence on the ground. To observe the physical nature of the solid waste in dustbins at different localities of the University and to categorize these sites for sample collection (Fig. 2). 


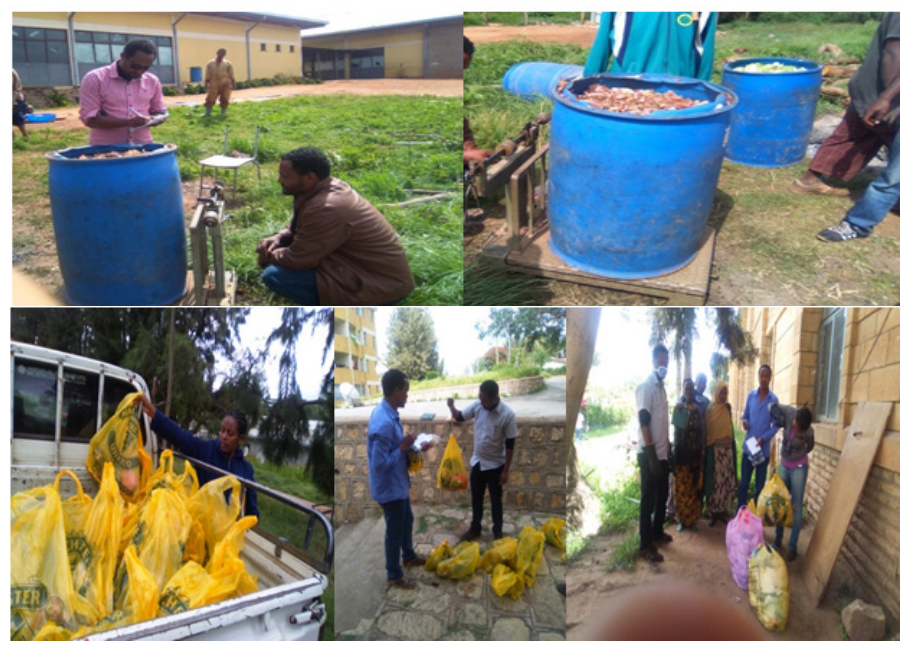

Fig. 2. Sample wastes collection from lounge and cafeteria (July 2015).

\section{Results and discussion}

The waste from major sources (HU) constitutes mainly compostable organic waste, including food leftovers. Food leftovers from student cafeteria, student lounge, cafes, and staff lounge were used to feed for animals in HU animal farm (Fig. 3). The remainder of the organic waste was collected and disposed of into open landfills. Bottles and cans from student lounge were collected separately and stored for sale.

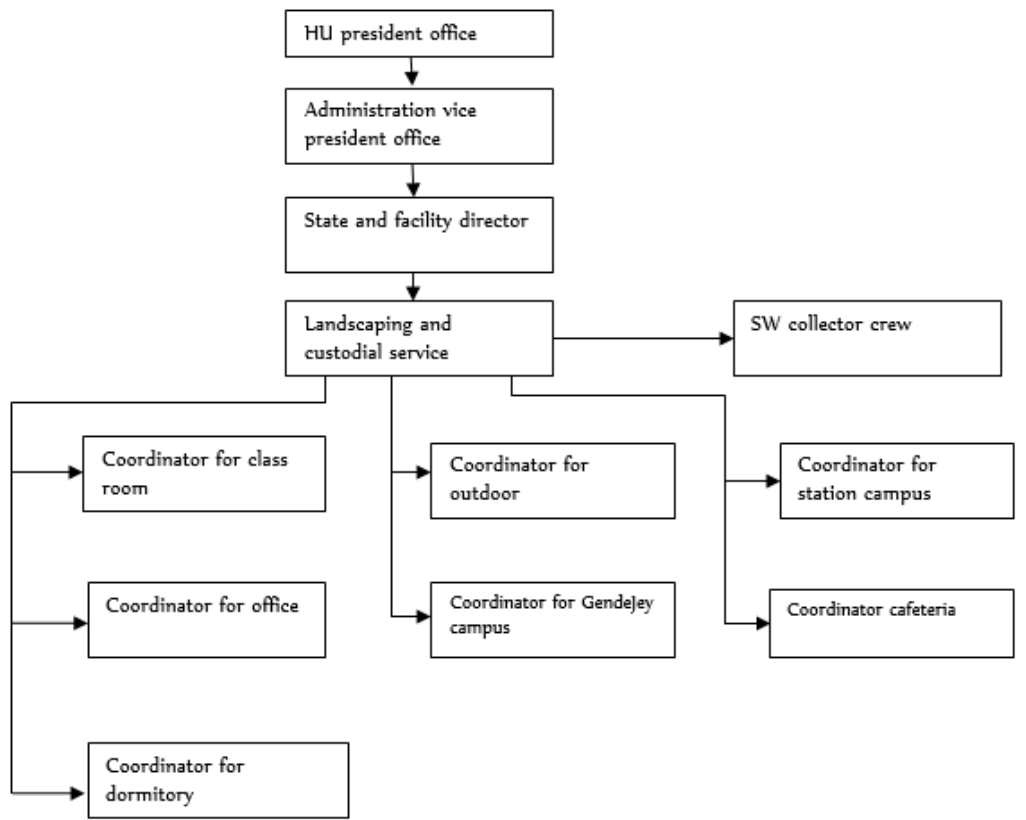

Fig. 3. The organizational structure of solid waste management in H.U.

Paper and cardboard waste generated from office, classrooms, and libraries burned in different sites on the campuses. For onsite storage plastic containers were available for each building. A tractor-trailer used for collection and transportation from on-site storage to 
the disposal site. These collection frequencies of solid waste were twice per day from the cafeteria and three times per week from residential areas.

\subsection{Waste generation}

The waste generation rate from Group-I (classrooms, offices, shops, laboratories, and libraries), Group-II (student cafeterias, student lounges, resource center, and staff lunges), Group-III (Staff residences), and Group-IV (Students dormitories) was estimated 353.07 $\mathrm{kg} /$ day, $943.12 \mathrm{~kg} /$ day, $806.06 \mathrm{~kg} / \mathrm{day}$, and $506.31 \mathrm{~kg} /$ day respectively. Generally, the total amount of municipal solid waste generated from HU was estimated to be $2608.56 \mathrm{~kg} / \mathrm{day}$. According to the data obtained from $\mathrm{HU}$ the number of graduate students, undergraduate students, administrative staffs and academic staffs on duty were 1613, 14,036, 2894, and 857 respectively. Therefore, the total contributing population number in HU was 19,400 (HU facts and figure 2015). Based on population data and the total amount of generated municipal solid waste per capita amounts of municipal solid waste generated on a daily basis and the estimated solid waste generation rate in HU main campus was 0.13 $\mathrm{kg} / \mathrm{cap} /$ day. This value falls within the ranges $(0.094-0.156 \mathrm{~kg} / \mathrm{capita} /$ day) reported for household \& academic institutional solid waste generation rate in Khulna metropolitan city [13]. Waste generation rate for Addis Ababa city $(0.127 \mathrm{~kg} / \mathrm{cap} /$ day up to $0.579 \mathrm{~kg} / \mathrm{cap} /$ day $)$ for the low, middle and high income level group [14] and the generation rate in rural areas (Less than $0.15 \mathrm{~kg} / \mathrm{cap} /$ day) reported for Asian countries [13]. However, it was less than the range (0.4-0.6 kg/cap/day) reported for low-income countries [15].

\subsection{Bulk density}

Measurement of solid waste density is a very important parameter for planning, scheduling, and designing of MSW management infrastructure. Accordingly, the bulk densities of solid wastes from different sources at HU were determined in Fig 4.

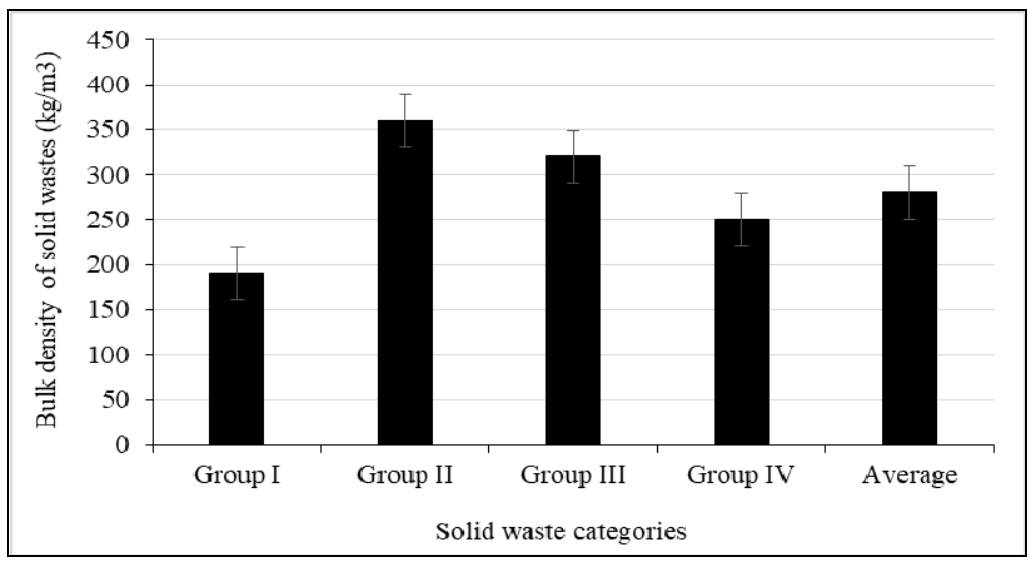

Fig. 4. Mixed municipal solid waste bulk density from different sources.

The highest bulk density of the waste was recorded from Group-II waste stream (364.42 $\left.\mathrm{kg} \mathrm{m}^{-3}\right)$. For a similar argument, the second highest bulk density was recorded from group III waste stream $\left(317.48 \mathrm{~kg} \mathrm{~m}^{-3}\right)$. These values fall within the range $\left(250-500 \mathrm{~kg} \mathrm{~m}^{-3}\right)$ reported for low-income countries [16]. The larger average bulk density of Group-III and Group-II waste stream could be due to the occurrence of high moisture containing waste like vegetables, fruit peels, Khat waste and fine materials (dust, ash, stones). The group I recorded the smallest bulk density of $189.82 \mathrm{~kg} \mathrm{~m}^{-3}$ and followed by group IV with 253.73 
$\mathrm{kg} \mathrm{m}^{-3}$ waste streams. This could be due to the occurrence of a higher fraction of paper waste. Generally, therefore the average bulk density MSW generated from HU is $281.36 \mathrm{~kg}$ $\mathrm{m}^{-3}$. This value falls within the range reported for Addis Ababa city (205-370 $\mathrm{kg} \mathrm{m}^{-3}$ ) and low-income countries $\left(250-500 \mathrm{~kg} \mathrm{~m}^{-3}\right)[16,17]$.

\subsection{Waste characterization}

The study employed in nine categories (Fig 5). These included paper, plastic, compostable organic matter (kitchen waste, Khat, leaves, grasses), cardboard, metals, glass, textiles, miscellaneous (wood, rubber, discarded shoes, dry cells, batteries), and fines (dust, ash, stones).

The large organic content (compostable organic matter) indicates that the necessity of recycling the organic wastes into valuable resources like compost (bio-fertilizer). Although institute of higher education is somewhat limited by the composting facilities of their region, universities are often more likely to have composting programs than the cities in which they are located [18]. A higher institutional institute like HU demonstrates the leadership role that all higher education institutions can play in improving local municipal organics management and overall environmental stewardship.

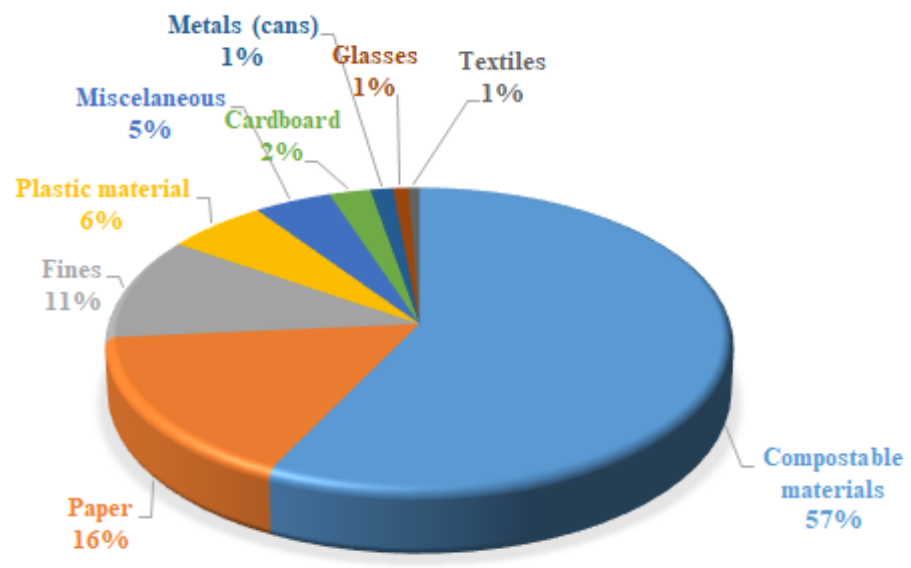

Fig. 5. Average waste composition from all sources.

\subsection{Potential for reuse, recycling and recovering}

Recycling, reusing, and recovery of wastes are an important component of integrated solid waste management as it decreases the load of waste going to the dumping site or for incinerating in Fig 6. For better waste management in HU, the study on the amount of waste generation and composition is very important to select a proper management system. As discussed in the above figure (Fig. 6) most of the generated wastes decomposable and organic. Furthermore, composting has many environmental benefits: improving soil health and structure, reducing the consumption of fertilizers and pesticides. In addition to compostable materials, the study revealed that there had been a generation rate of potentially recyclable materials, that is 177.48 tonnes/year of papers and cardboard, 55.43 tonnes/year of plastic material, and 12.42 tonnes/year of metals (can) (Table 1).

The estimated calorific value of HU composite MSW was around $22,877.68 \mathrm{KJ} / \mathrm{kg}$. The heating value of coal is about $37-40 \mathrm{MJ} / \mathrm{kg}$ [19], this means that the energy that can be 
produced by one kilogram of coal, it can be produced by two kilograms of municipal solid waste.

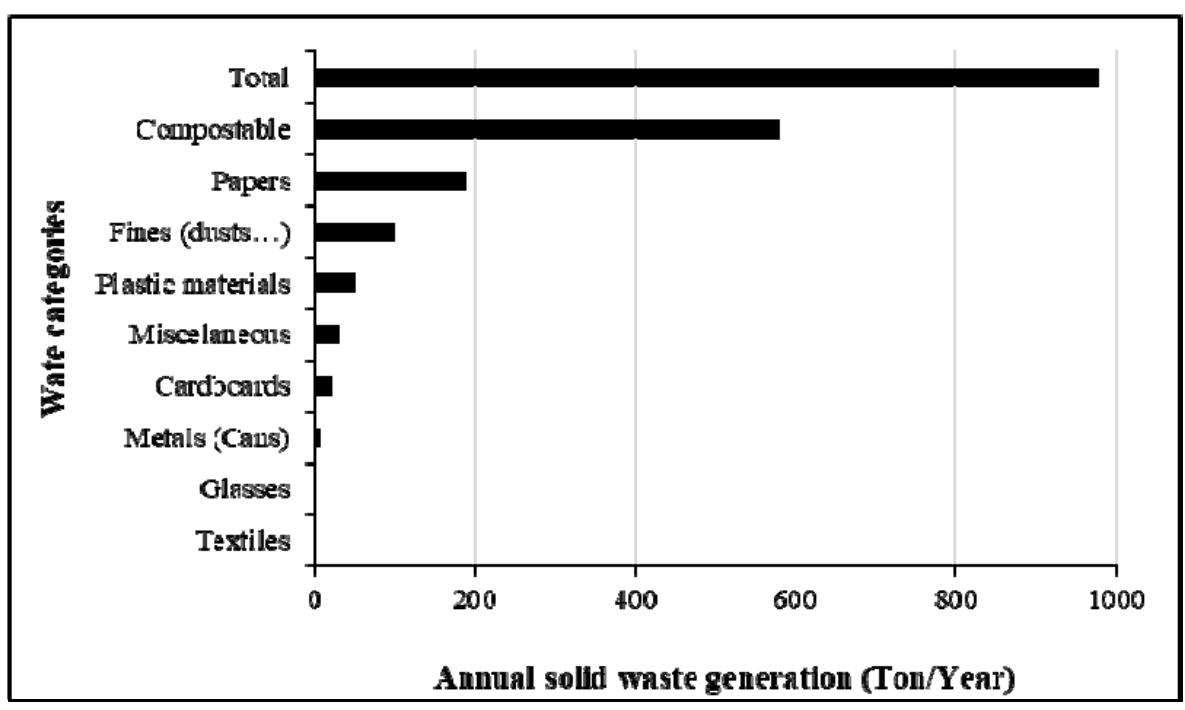

Fig. 6. Annual mean solid waste generations rate at HU (ton/year).

Table 1: Recommended solid waste management options for HU MSW.

\begin{tabular}{|c|c|c|c|c|c|}
\hline & & Recomme & $\begin{array}{r}\text { solid waste } \mathbf{n} \\
\text { MS }\end{array}$ & gement optio & for $\mathrm{HU}$ \\
\hline Solid Wa & е Тype & $\begin{array}{l}\text { Estimated } \\
\text { generation } \\
\text { (ton/year) }\end{array}$ & $\begin{array}{c}\text { Recyclable/ } \\
\text { Reusable } \\
\text { Material }\end{array}$ & $\begin{array}{c}\text { Recoverable } \\
\text { Material }\end{array}$ & $\begin{array}{l}\text { Landfill } \\
\text { Disposal }\end{array}$ \\
\hline Paper and & Irdboard & 177.48 & $\checkmark$ & & \\
\hline Fines (dust, as & stones etc.) & 104.61 & & & $\checkmark$ \\
\hline Plastic $\mathrm{r}$ & terial & 55.43 & $\checkmark$ & & \\
\hline Tex & & 6.03 & $\checkmark$ & & \\
\hline Gla & & 8.33 & $\checkmark$ & & \\
\hline Metals & can) & 12.42 & $\checkmark$ & & \\
\hline Miscellaneous & $\begin{array}{l}\text { Wood, } \\
\text { rubber and } \\
\text { discarded } \\
\text { shoes }\end{array}$ & 42.40 & $\checkmark$ & & \\
\hline & $\begin{array}{l}\text { Dry cells, } \\
\text { batteries, } \\
\text { bones etc. }\end{array}$ & & & & $\checkmark$ \\
\hline Compostab & materials & 546.08 & & $\checkmark$ & \\
\hline Total & & 952.78 & 302.09 & 546.08 & 147.01 \\
\hline
\end{tabular}


In general, the high average amount of heating value (about $22,877.68 \mathrm{KJ} / \mathrm{kg}$ ) and the proximate analysis result of HU composite MSW shows the feasibility of design the waste to energy plant such as incineration. However, incinerators require a large capital investment with little economic return. Also, the plants need a constant supply of waste for maintaining optimal combustion [20-22].

\section{Conclusions}

According to the field survey and discussion with concerned bodies, the current solid waste management practice is not satisfactory. Even though food leftovers from student cafeteria, student lounge, student cafe, and staff lounge were used as feed for animals in HU, but other organic wastes were collected and disposed of into open (uncontrolled) landfills. Paper and cardboard waste generated from offices, classrooms, and libraries were burned in different places on the campuses, which have significant environmental implications. Generally, waste minimization techniques such as recycling, composting, and energy recovery practices were insufficient in the HU. The study revealed that the total amount of MSW generation rate per day at HU is estimated to be $2608.56 \mathrm{~kg} /$ day. The per capita solid waste generation rate was estimated to be $0.134 \mathrm{~kg} / \mathrm{cap} /$ day. The generation rate was lower compared to the generation rate of low-income countries [23-24].

The results demonstrated that the physicochemical composition of selected compostable material from MSW was suitable for the composting process. In general, considering the climatic conditions and other factors, composting of the selected organic matter is suited for HU municipal solid waste and windrow composting could be the best option to deal with the considerable volume of compostable waste. This type of recovery should be adapted to recycle the organic residues as a waste management option and income generation. In addition to compostable materials, the study revealed that there had been a generation rate of potentially recyclable 169.45 tonnes/year papers and carton, 59.49 tonnes/year plastic material, and 11.82 tonnes/year metals (can). These materials should be collected separately (source separation) and can be a means of income generation to the institute.

We acknowledge Haramaya University supported the fieldwork, and the Ministry of Agriculture provided material and technical for the analysis of the collected sample. Schlumberger Foundation, Faculty for the Future is much appreciated for providing financial support for this study. Special thanks go to the local community for their kind support and assistance during sample collection and field survey.

\section{References}

1. G. Tchobanoglous, F. Kreith, Handbook of solid waste management (McGraw-Hill, New York, 2002)

2. UNEP, The Framework of the global partnership on waste management, note by Secretariat. http://www.unep.or.jp/Ietc/SPC/newsnov10/3_FrameworkOfGPWM.pdf (2018)

3. ISWA, UNEP, Waste Management: Industry as a partner for sustainable development. (International Solid Waste Association and United Nations Environment Program, 2002)

4. WWF, Getting at the source: Strategies for reducing municipal solid waste (Island Press, Washington DC, 1991)

5. S. Amini, M. Fremerey, M. Wesseler, Towards a shared vision for higher education, cross cultural insights \& projects (University of Kassel, Germany, 2002) 
6. Y.M. Mesfin, K.T. Kibret, PLoS One 8, 11 (2013)

7. B. Shimelis, Int. J. Environ. Prot. 1 (2011)

8. C. Armijo, S. Ojeda-Benítez, E. Ramírez-Barreto, Resour. Conserv. Recy. 39 (2003)

9. A. Allen, Institutional environmental change at Tulane University (Tulane University, New Orleans, 1999)

10. G. Tchobanoglous, H. Theisen, S. Vigil, Integrated solid waste management (McGraw-Hill, New York, 1996).

11. US EPA, Composting of yard trimmings and municipal solid waste (US Environmental Protection Agency Office of Solid Waste and Emergency Response, 1994).

12. G. Cochran, Sampling techniques (Wiley Series in Productivity and Applied Mathematical Statistics, New York, USA, 1977)

13. UDEPA, Solid waste management in Asia (World Bank, Washington DC, 1999)

14. S. Kathiravalea, M. Yunusa, K. Sopianb, A. Samsuddin, Modeling the heating value of municipal solid waste and fuel (World Bank, Washington DC, 2003)

15. ASTM, Standard Test Method for Determination of the Composition of Unprocessed Municipal Solid Waste (1988)

16. H. Mohd, Z. Ridzma, J. Appl. Sci. 12, 11 (2012)

17. B. Yami, Proceedings of the 25th WEDC International Conference (1999)

18. F. Heylighen, Encyclopedia of life support systems (2001)

19. P. Connett, E. Connett, The Ecologist 24, 1 (1994)

20. I. Barmina, A. Lickrastina, M. Zake, A. Arshanitsa, V. Solodovnik, G. Telisheva, Chem. Eng. Trans. 29 (2012)

21. CURC, College and University Recycling Council, http://www.nrcrecycle.org/councils/CURC/default.htm (2001).

22. L. Irene, Environmental engineers' handbook (CRC Press, New Jersey, 1999)

23. N. Scarlat, V. Motola, J. Dallemand, F. Monforti-Ferrario, L. Mofor, Renew. Sust. Energ. Rev. 50 (2015)

24. N. P. Thanh, Y. Matsui, T. Fujiwara, Env. Monit. Assess. 175 (2011) 